\title{
Development strategy of culinary business employing the Blue Ocean Strategy (BOS)
}

\author{
S Ardian ${ }^{1 *}$ B Syairudin ${ }^{1^{* *}}$ \\ ${ }^{1}$ Department of Industrial Engineering, Institut Teknologi Sepuluh Nopember (ITS) \\ Surabaya, Indonesia \\ *sonny.ardhian23@gmail.com \\ **bambangsy@yahoo.com
}

\begin{abstract}
Culinary business development is now growing quite rapidly, Surabaya became one of the target markets of domestic and foreign businessmen in culinary business. The high competition in the culinary business is a powerful reason to apply the right business strategy to be able to survive and win the competition. One of the method that can be used in offering business strategy is the Blue Ocean Strategy (BOS). By identifying the strengths, weaknesses, opportunities and threats (SWOT) of the business strategy and then designing the blue ocean strategy which is taken as a metaphor to represent these industries that may offer greater opportunity or higher profit potential. This is the goal of blue ocean strategy, to search for and gain unexplored market space instead of engage in traditional competition. The object of observations in this study is spicy noodle business. This study aimed atdeveloping a business strategy formulation with BOS and providing alternative solutions for business development to the management that agree with the socio-cultural conditions of Surabaya. The results showed that there are two strategies that should be eliminated, like the strategiesof offeringfranchise without royalty fees and no separation of smoking and non-smoking area. There are three strategies that should be reduced, such as reducing educative wall posters, reducting door prizes and photo contest, and reducing the amount of franchise. There are six strategies that can be improved, namely increasing serving time, being efficient of tables arrangement, providing employment for local residents, strategic location closes to several colleges, photobooth (selfie corner) for consumers and increasing the uniquenessconcept of the shop. The alternative solutions of business development can be done by adding facilities such as Wi-Fi connection and air conditioning (AC) installationto comfort theconsumers,guest comment (online and offline suggestion box), and membership (visitors' ID).
\end{abstract}

Keywords: Franchise, Culinary Business Development Strategy, Management Strategy and Blue Ocean Strategy.

\section{Introduction}

Culinary business is one of businesses that has potential to growing quite rapidly. It has been growing into a lot of franchise model. According to Astuti (1), there are several factors encouraging its growth, namely the characteristics of the franchise itself, the increase of purchasing power, the availability of 
resources with the required expertise, high of return on investment, and internal factors such as motivation, open personality, in line with lifestyle changes. As the second metropolitan city after Jakarta, Surabaya is a market place targeted by many domestic and foreign entrepreneurs. Based on the data from BPS (2), the number of business culinary entrepreneurs in Surabaya is increasing every year. The data shows from 2013, 6.32\% of culinary business entrepreneurs rises to $6.43 \%$ by 2014, and in 2015 rises to $6.64 \%$. The rapid development of the culinary business in Surabaya causing intense competition among the business entrepreneurs. To maintain their business, the business entrepreneurs have to establish a positive image of their business through a brand. In granting a brand, the most important thing is to identify and differentiate (distinguish) the goods or services of a seller from goods or services of other sellers (3).

One approach that could be applied in offering business strategy is by using the Blue Ocean Strategy (BOS). BOS is a business strategy that is appropriate for being used in the face of such competition. BOS could find a new space in the business to improve business efficiency and process of performance (4). Blue Ocean Strategy is characterized by an unexplored market space, demand creation and growth opportunities, which are very favorable. At Red Ocean Strategy, the restrictions on the industry have been defined and accepted, and the rules of competition have been known (5). BOS formulation would create value innovation that affect the cost structure and value proposition for buyers in a positive way. Value innovation leads the company on a leap of value for buyers and for the company itself. Establishing positive image has been created by the brand whose done by one of the noodle shop in Surabaya, namely "Mie X". It not only offers a unique name, but also applies an interesting concept. However, until now on, "Mie X" still not implementing the business strategies, specifically for their business development. Therefore, this study aimed at determining the formulation of business strategy with the approach of the Blue Ocean Strategy (BOS) upon "Mie X", Surabaya and providing the alternative solutions to the management of enterprise development of "Mie X" which agree with the socio-cultural conditions in Surabaya.

\section{Methods}

This research consists of 6 stages: business strategy identification, preparation and distribution SWOT and expert questionnaire, processing SWOT questionnaires and expert questionnaires, identification the attributes of BOS,preparion and distribution BOS questionnaires, and designing strategy canvas and BOS.

\subsection{Stage of Business Strategy Identification}

At this stage, the first thing to do is identifying the attributes, which are associated with the business strategies that have been implemented by the company. There are 10 attributes constitute the strength of the business strategy of Mie X namely a concept of unique shop, photobooth (selfie corner) for the consumers, educative wall posters, door prizes and photo contest, a strategic location closes to several colleges, reasonable prices, the concept of unique names for menu, offering franchise without royalty fees, has been sertified halal from MUI, and providing wide parking area. On the other hand, 5 attributes constitute the weakness of Mie $\mathrm{X}$ is the availability of Wi-Fi connection, serving time, availability of air conditioner (AC), arrangement of the tables, and separation for smoking and non-smoking area. There are 3 attributes that represent opportunities of business strategy upon Mie X namely providing employment for local people, being one of the culinary object in Surabaya, and high enthusiasm of Surabaya residents on spicy food. Whereas, for the threats, there are 2 attributes; the number of new shops that use the concept of spicy food and the number of franchise concepts.

\subsection{Stage of Preparation and Distribution SWOT Questionnaires}

The sampling method employed the method of convenience sampling, is a specific type ofsampling method relies on manner that selected because of their convenient accessibility and proximity to reach. Convenience sampling is a non-probability sampling method, which each unit in the population does not have the same chance to be selected as the sample of the study. This study conducts the first 
questionnaires distribution to identify business strategies of Mie X and the competitors. Questionnaires were distributed to 10 respondents of each competitors and experts, whom are the owner of Mie $\mathrm{X}$ and culinary experts.

\subsection{Stage of Processing SWOT Questionnaires and Expert Questionnaires}

The results of data survey were processed using SPSS and the weight values were calculated using MS. Excel until obtained the identification of strategies that have been implemented and strategies that have not been implemented by the competitors and should be developed by the company. The results of these questionnaires will be used as a reference for preparing BOS questionnaires.

\subsection{Stage of Identification the Attributes of BOS}

Determining attributes were gained from the results of recapitulation of the questionnaire of identifying business strategies as well as the addition from the experts questionnaire. From the identification of internal factors, there are 4 attributes eliminated, while of external factors, there are 2 attributes of chance and 1 attribute of threat eliminated. Then, there are 2 additional attributes of the results of questionnaires and interviews by experts, namely the provision of a guest comment (online and offline suggestion box) and membership (visitors' ID).

\subsection{Stage of Preparation and Distribution BOS Questionnaires}

The collection of the questionnaire was executed by distributing questionnaires using convenience sampling based on the consumers who visited Mie X, in which to determine the amount of sample that would be determined using manual calculation with Slovin formula. The population that was being used is derived from the minimum amount of visitors in Mie X, namely 200 people.

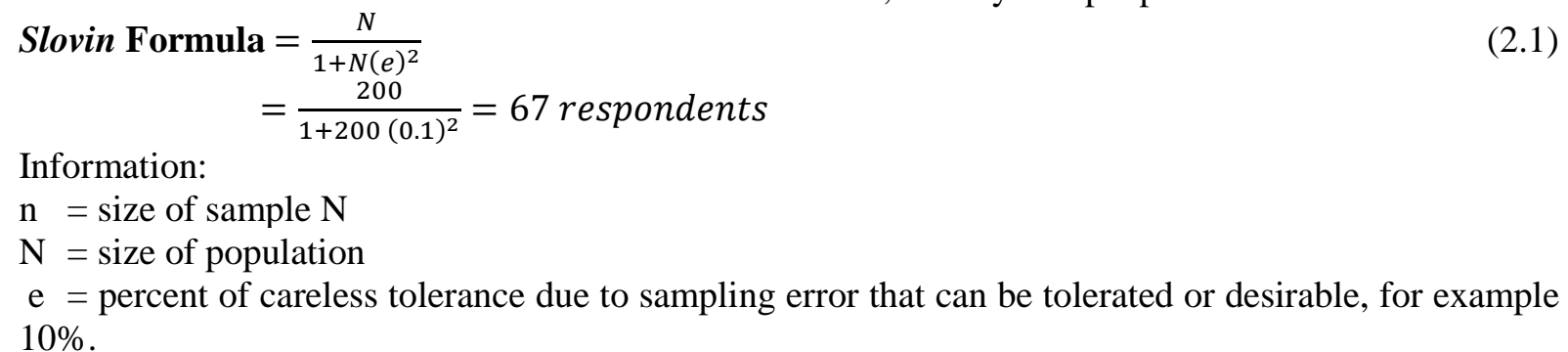

\subsection{Stage of Designing Strategy Canvas and BOS}

Preparation and determination of variable combinations carried out to see a combination of variables that will provide optimal results to the company. 


\section{Findings and discussion}

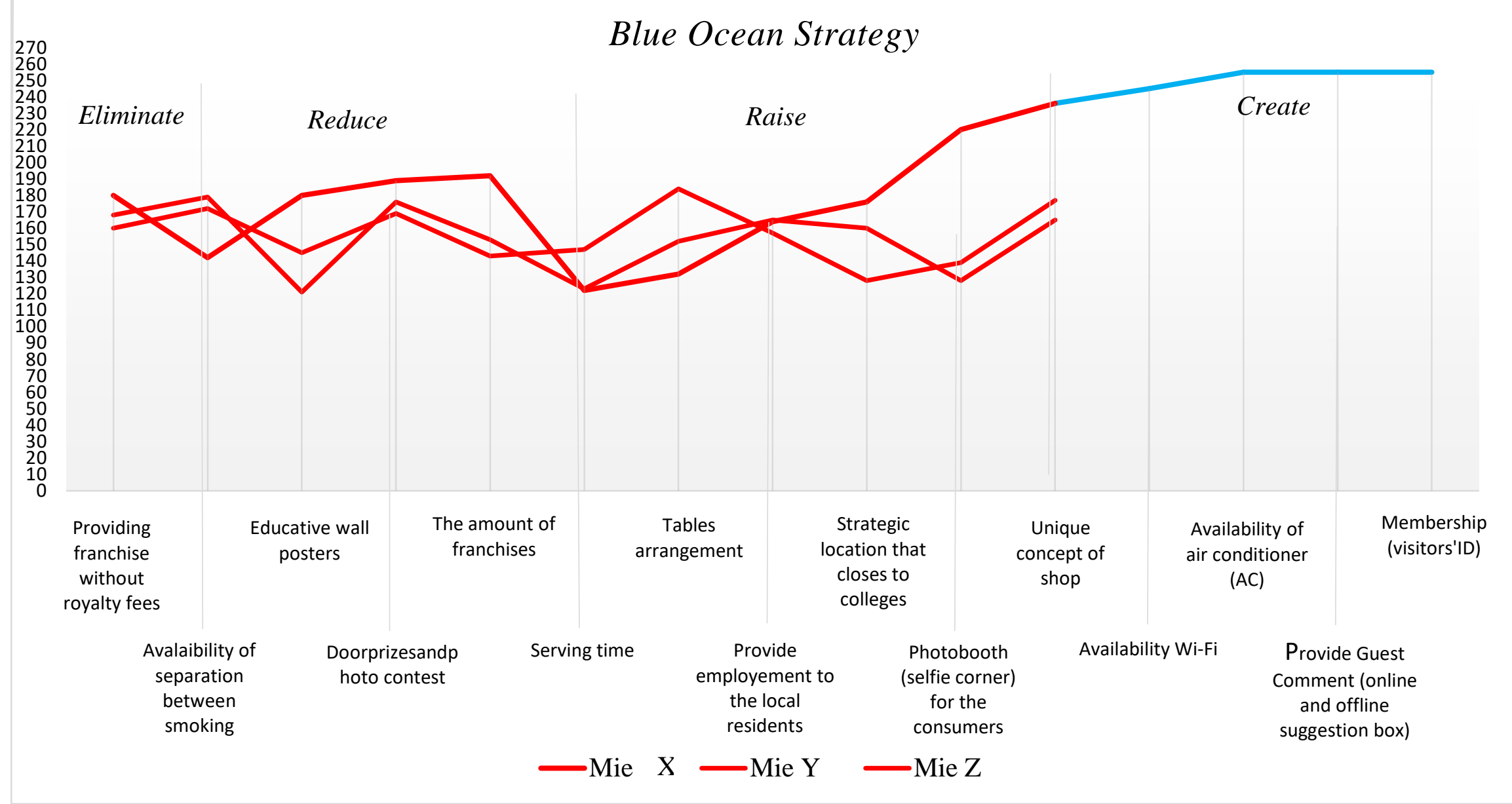

Figure 1.Blue Ocean Strategy. 
The results as shown in figure 1 is obtained after the reseacher distributing the questionnaires. Early questionnaires were distributed to identify the business strategy of Mie $\mathrm{X}$ and competitors. The questionnaires were distributed to 10 respondents to each competitor and expert, where the expert was the owner of Mie X and a culinary expert. Recapitulation and identification for BOS questionnaires were then performed. To determine the number of samples, this research used a manual calculation with Slovin formula. The number of population participated in this research is the minimum number of Mie $\mathrm{X}$ visitors that is 200 people. Then the researcher Slovin formula,

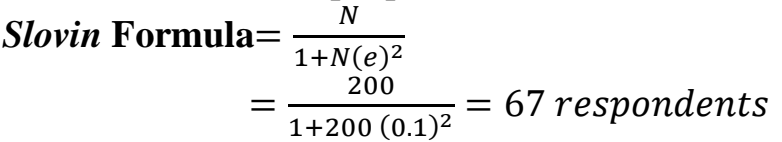

Information:

$\mathrm{n}=$ size of sample $\mathrm{N}$

$\mathrm{N}$ = size of population

$\mathrm{e}=$ percent of careless tolerance due to sampling error that can be tolerated or desirable, for example $10 \%$.

To know the respondents' characteristics of Mie X, it used the following variables:

a) Demographic Variables: this variable consists of gender, age, marital status, education, occupation, and income.

b) Behavioral Variables: this variable consists of the frequency of the culinary business and the character of the visit.

This is how the numbers in figure 1 are obtained, whereas there were previous nubers obtained from data collection and processing. The recapitulation of the data is presented in the following table1.

Table1. Recapitulation of Canvas Calculation Strategy.

\begin{tabular}{|c|c|c|c|c|}
\hline \multirow{2}{*}{ No } & \multirow{2}{*}{ Consumer Needs } & \multicolumn{2}{|c|}{ Weight } & \multirow[b]{2}{*}{ MieZ } \\
\hline & & MieX & MieY & \\
\hline 1 & Unique concept of shop & 236 & 165 & 177 \\
\hline 2 & $\begin{array}{l}\text { Photobooth (selfie corner) fo } \\
\text { the visitors }\end{array}$ & 220 & 128 & 139 \\
\hline 3 & Educative wall posters & 180 & 121 & 145 \\
\hline 4 & Doorprize and photo contest & 189 & 176 & 169 \\
\hline 5 & $\begin{array}{l}\text { Strategic location that closes } \\
\text { to colleges }\end{array}$ & 176 & 160 & 128 \\
\hline 6 & $\begin{array}{l}\text { Providing franchise without } \\
\text { royalty fees }\end{array}$ & 180 & 168 & 160 \\
\hline 7 & Availability Wi-Fi & 97 & 90 & 95 \\
\hline 8 & Serving time & 122 & 123 & 147 \\
\hline 9 & $\begin{array}{l}\text { Availability of air conditioner } \\
\text { (AC) }\end{array}$ & 104 & 120 & 119 \\
\hline 10 & Table arrangement & 132 & 152 & 184 \\
\hline
\end{tabular}


Table2. Recapitulation of Canvas Calculation Strategy (Con’t)

\begin{tabular}{clccc}
\hline No & \multicolumn{1}{c}{ Consumer Needs } & Meight & MieY & MieZ \\
\hline 11 & $\begin{array}{l}\text { Avalaibility of separation } \\
\text { between smoking andnon- } \\
\text { smoking area }\end{array}$ & 142 & 179 & 172 \\
12 & $\begin{array}{l}\text { Provide employement to the } \\
\text { local residents }\end{array}$ & 164 & 165 & 157 \\
13 & $\begin{array}{l}\text { Total of franchise } \\
\text { Provide Guest Comment } \\
\text { (online and offline suggestion }\end{array}$ & 192 & 153 & 143 \\
14 & $\begin{array}{l}\text { box) } \\
\text { Membership (visitors ID) }\end{array}$ & 89 & 82 & 88 \\
\hline
\end{tabular}

In the data collection of identification business strategy of the competitors obtained results regarding to the presence or absence of the application of business identification on each competitor. As for the experts, it was used the weights that could illustrate the positions of culinary business that currently exists. The higher the weight resulted, the more culinary businesses have been increasingly applying these strategies, so that the elimination of strategies needs to be executed based on the calculation of weight strategy. There are four strategies that eliminated on the power indicator. Reasonable price strategy, the concept of interesting name of the menu, and a wide parking area are eliminated, because there are two competitors applied the similar srategies, it is supported by the experts weight calculation which demonstrate high weight value of 0.3 . Likewise, the strategy of has been certified halal by MUI, and this strategy gained the highest weight value, it shows that in the culinary business, this strategy has been widely applied. There are 2 strategies eliminated on the chance indicator, namely being one of culinary objects in Surabaya and high enthusiasm of residents in Surabaya to the spicy foods. The two competitors have been implementing the similar strategies, it is supported by the expert weight calculation that shows the highest weight value of 0.6. It shows that in culinary business, this strategy has been widely implemented. Strategy of providing employment to the local residents being the only one chance to be developed. By hiring local residents could be the form of corporate social responsibility of the culinary business, and improve the image and brand of the culinary business in society, also there is 1 strategy eliminated on the indicator of chance, namely the number of new shops that used the concept of spicy foods, which gained the highest weight value of 1.14, it shows that this strategy has been commonly implemented.

\subsection{Analysis of Strategy Canvas and Blue Ocean Strategy}

In this analysis, strategies are categorized into 4 parts, namely eliminate, reduce, raise and create.

\subsubsection{Eliminate}

From the results of designing strategis based on the blue ocean strategy ilustrated in Figure 1. There are 2 strategies involved in the eliminate category, specifically:

- Providing franchise without royalty fees

The increase of business opportunities deals with no royalty fees for the culinary business development would prejudice the founder (original brand), because when the transaction is breakingbuy, there will be no quality checks for the franchise, so that when one franchise does not maintain the quality of the product, it can be bad for the original brand. Therefore, this strategy should be eliminated, otherwise given charge of $5-10 \%$ royalty, that will be used as the capital to carry out inspections of each franchise to maintain the original brand quality and reputation. 
- Avalaibility of separation for smoking andnon-smoking area

This strategy needs to be eliminated, because the separation can have an impact on less efficient moves of the consumers caused by selecting area. In addition, this strategy had no significant impact on the development of the business. The solutions that can be applied to minimize the impact of the elimination of this strategy is the implementation of good air circulation and ventilation, and well arrangement of tables and chairs, so that the room can be more comfortable.

\subsubsection{Reduce}

From the results of desining strategies based on blue ocean strategy in Figure 1. There is 3 strategies involved in reduce category, specifically:

- Educative wall posters

Reducing the number of wall posters is executed to minimize expenditure as well as minimize the space, so that the room looks more spacious. In order to always provide the latest educational information, it can be done the replacement posters regularly in order to attract and educate the visitors.

- Doorprizeand photo contest

Reducing doorprize and photo contest is done by minimizing the implementation of this strategy related to the certain eventonly, so it is not held every month, which spends the fund, and focuses on this strategy.

- The amount offranchise

Reducing the amount of franchise needs to be done to minimize competition among branches in one city which can whittle down the uniqueness of the culinary business. The grand opening can be done in a city that has not had this culinary, so it can develop the market and introduce the brand to the wider community.

\subsubsection{Raise}

From the results of designing strategies based on the blue ocean strategy in Figure 1 . There are 6 strategies involved in the raise category, specifically:

- Time serving

Increasing this strategy needs to be done to make the consumers more convenient and reduce the waiting time that makes the consumers are saturated, additionally, it makes the consumers become faster to turn around. This can be done by preparing the required ingredients carefully and determining the placement of employees in the proper work station, so that employees can work on a regularly based on their job description.

- Tables arrangement

Table arrangement efficiently can accelerate the flow velocity and allocation of effective consumer. This can be improved by the use of tables and chairs that can be separated so it can be easy to adjust with the number of visitors.

- Providing employment to the local residents

It opens employment opportunities for local residents in Surabaya by providing many jobs.

- Strategic location closes to the colleges

This strategy is done to find strategic location to develop new branches, so that it can approach the desired target market.

- Photobooth (selfie corner) for the consumers

Designing pojok selfie (selfie corner) for the consumers by applying photobooth with periodically changed in order to make the visitors are not saturated.

- Unique concept of shop

Improving the strategy of decorations as well as the unique culinary concept needs to be done to attract the customers to visit. The concept of prison, which has been applied now including shop decoration, prisoners uniform employees, as well as custody cutlery. The improvement can be done 
with variety uniforms of the employee, that is the concept of police or jailer. In addition, it is better to provide the uniforms for the consumers who want to wear the uniform in order to reinforce the concept that has been used today. This uniqueness may be the main attraction for foreign and local objectists.

\subsubsection{Create}

From the results of designing strategy of the blue ocean strategy in figure 1. There are 4 strategies involved increate category, specifically:

- Availability Wi-Fi

Availability Wi-Fi can be an additional attraction of the culinary business. With this addition the consumers can access social media quickly, share culinary information, as well as recommend and write testimony the culinary business. It can be a media campaign for the culinary business.

- Availability of air conditioner(AC)

Installation of AC can be done as a plus for the culinary business since it can comfort of the consumers which is one of the important aspects that need to be considered especially if the culinary business offers the concept of spicy foods.

- Providing Guest Comment (online and offline suggestion box)

Providing facilities such as suggestion boxes placed at shop as well as providing social media and email for consumers testimony. This strategy is done to establish a quick system in handling the complaints.

- Membership (visitors’ ID)

Providing a membership card for the customers to facilitate information access the promo for dinner, additionally this card also used to record visitors and be more interactive with visitors.

\section{Conclusion and suggestion}

This study concludes:

- From the results of designing strategy based on the blue ocean strategy there are 2 strategies involved in eliminate category, 3 strategies involved inreducecategory, and 6 strategies involved in raise category.

- Alternative solutions of business development are providing additional facilities such as Wi-Fi connection and AC installation in order to comfort the consumers, guest comment (online and offline suggestion box) placed in the shop, also social media and email for the consumers testimony, and membership (visitors' ID) to facilitate information access the promo for dinner, additionally this card also used to record visitors and be more interactive with visitors. The development of the concept of prison by providing various uniforms worn by the employee such as police and jailer uniforms. Moreover, providing additional uniforms for the customers who want to wear the costume can be done as a strategy to strengthen the concept that has been applied.

This study suggests for the future study which will take the similar interest to scope the research in the culinary business with the concept of spicy noodles. Therefore, it would be better to conduct research on overall concepts of noodles culinary by doing classification based on the type of noodles so that the results would be more credible.

\section{References}

1. Astuti D. Kajian bisnis franchise makanan di Indonesia. J Manaj dan Kewirausahaan. 2005 May 2;7(1):83-98.

2. Badan Pusat Statistik (BPS) Kota Surabaya. Kota Surabaya Dalam Angka Vol. 1. Surabaya: Badan Pusat Statistik (BPS) Kota Surabaya; 2016.

3. Kotler P. Manajemen pemasaran Jilid 2 [Internet]. Jakarta: Indeks; 2007. Available from: http://library.um.ac.id/free-contents/printbook2.php/koleksi-digital-perpustakaan-33047.html

4. Sidharta, Holil AAN. Perencanaa portofolio aplikasi pada contact center Telkom area Surabaya 
menggunakan pendekatan Blue Ocean Strategy (BOS) dan Balance Scorecard (BSC). In: Prosiding Seminar Nasional Manajemen Teknologi XIV. 2011.

5. Kim WC, Mauborgne R. Blue ocean strategy (strategi samudera biru) : ciptakan ruang pasar tanpa pesaing dan biarkan kompetisi tak lagi relevan. Jakarta: Serambi; 2005. 315 p. 